\title{
Physical and chemical characteristics of common bean varieties
}

\section{Características físicas e químicas de diferentes variedades de feijão comum}

\author{
Marcio de Barros $^{1 *}$; Sandra Helena Prudencio ${ }^{2}$
}

\begin{abstract}
The common bean (Phaseolus vulgaris L.) is one of the most widely consumed legumes in the world, but nevertheless different varieties vary with respect to their physical and chemical aspects. This study evaluated the physical and chemical characteristics (color, hardness after cooking, water absorption capacity, cooking time, integrity of the beans after cooking, proximate composition and mineral composition) of the following varieties of the common bean: Carioca, IAPAR 81, Saracura, Juriti, Pérola, Colibri and IAPAR 31, all destined for both the internal Brazilian and external markets. The varieties studied had different proximate compositions and contents of the following minerals: $\mathrm{K}, \mathrm{Ca}$, $\mathrm{N}, \mathrm{Mg}, \mathrm{S}, \mathrm{Cu}, \mathrm{Fe}$ and $\mathrm{Mn}$; but identical contents of $\mathrm{P}, \mathrm{Zn}$ and $\mathrm{B}$. The beans were classified as small in size. The Carioca variety showed the lowest values for $\mathrm{L}^{*}$ (41.29) and $\mathrm{H}^{*}$ (57.22), and the highest values for $\mathrm{a}^{*}$ (12.17), its beans being redder and darker than the others. The Saracura variety showed the lowest degree of hydration $(95.70 \mathrm{~g} / 100 \mathrm{~g})$, cooking time (22.67 min.) and whole beans after cooking (30\%), while the Pérola variety showed the highest values for these same parameters, $106.77 \mathrm{~g} / 100 \mathrm{~g}$, $43.67 \mathrm{~min}$. and $82.16 \%$, respectively. No correlation was observed between the calcium and magnesium contents of the beans and the hardness of the raw bean, degree of hydration during maceration, cooking time and integrity of the cooked beans. According to the characteristics studied, the Saracura variety is a good option for both industrial and domestic use.
\end{abstract}

Key words: Bean. Cooking time. Hardness. Proximate composition. Color. Minerals. Degree of hydration.

\section{Resumo}

O feijão comum (Phaseolus vulgaris L.) é uma das leguminosas mais consumidas no mundo, no entanto, os grãos das diversas variedades diferem quanto a aspectos físicos e químicos. Foram avaliadas características físicas e químicas (cor, dureza do grão após cozimento, grau de hidratação, tempo de cozimento, integridade após o cozimento, composição centesimal e conteúdo de minerais) de feijão comum variedades Carioca, IAPAR 81, Saracura, Juriti, Pérola, Colibri e IAPAR 31, destinadas ao comércio interno e externo. As variedades estudadas apresentam diferenças na composição centesimal e teores dos minerais $\mathrm{K}, \mathrm{Ca}, \mathrm{N}, \mathrm{Mg}, \mathrm{S}, \mathrm{Cu}, \mathrm{Fe}$ e $\mathrm{Mn}$; mas teores idênticos de $\mathrm{P}, \mathrm{Zn}$ e B. Quanto aos parâmetros de cor a variedade Carioca apresentou menores valores de $\mathrm{L}^{*}(41,29)$ e $\mathrm{H}^{*}(57,22)$, e maior valor de $\mathrm{a}^{*}(12,17)$, possuindo grãos mais avermelhados e mais escuros que os das demais. A variedade Saracura teve o menor grau de hidratação $(95,70 \mathrm{~g} / 100 \mathrm{~g})$, tempo de cozimento $(22,67 \mathrm{~min})$ e de grãos íntegros após o cozimento (30\%), enquanto que a variedade Pérola apresentou valores mais elevados, de 106.77 g/100g, 43,67 minutos e 82,16\% respectivamente. Não foi observada correlação entre teores de cálcio e magnésio dos grãos com a dureza do grão cru, grau de hidratação durante a maceração, tempo de cocção e integridade dos grãos cozidos. De acordo com as características estudadas a variedade Saracura é uma boa opção tanto para uso doméstico como industrial.

Palavras-chave: Feijão. Tempo de cocção. Dureza. Composição centesimal. Cor. Minerais. Grau de hidratação.

${ }^{1}$ Prof. Dr., Dept ${ }^{\circ}$ de Bioquímica e Biotecnologia, Centro de Ciências Exatas, Universidade Estadual de Londrina, UEL, Londrina, PR, Brasil. E-mail: marciodebarros@hotmail.com

${ }^{2}$ Prof $^{\mathrm{a}} \mathrm{Dr}^{\mathrm{a}}$, Dept ${ }^{\mathrm{o}}$ de Ciência e Tecnologia de Alimentos, Centro de Ciências Agrárias, UEL, Londrina, Brasil. E-mail: sandrah@ uel.br

* Author for correspondence 


\section{Introduction}

The common bean (Phaseolus vulgaris L.) is a traditional food in the human diet, has low lipid content and is rich in proteins, vitamins, complex carbohydrates and minerals (GRAHAM; RANALLI, 1997; SHIMELIS; RAKSHIT, 2005; COSTA et al., 2006; ANTON et al., 2008; TOLEDO; CANNIATTI-BRAZACA, 2008; MONTOYA et al., 2008; GATHU; NJAGE, 2012).

Economically, beans are very important for Brazil; production and exports have increased greatly in recent years. According to the National Supply Company (COMPANHIA NACIONAL DE ABASTECIMENTO - CONAB, 2008), Brazilian bean production in 2007 and 2008, considering all three harvests, amounted to 3.44 million tons, about $2.9 \%$ higher than that obtained in 2007 . The area cultivated in the three harvests was estimated at 3.83 million hectares, $6.3 \%$ less than the harvest in 2006/2007. Brazilian consumption of beans was estimated at 3.4 million tons per year, imports at 70,000 tons and exports at 30,000 tons.

Beans present great variety in color, size, chemical composition and hardness, depending on the cultivar to which they belong. These differences come from intrinsic factors (genotype, which is partially responsible for the differences between cultivars and varieties) or from extrinsic factors such as storage conditions, type of cultivation soil, agronomic practices and climatic and technological factors (GONZÁLEZ et al., 2006; AMIR et al., 2007; MONTOYA et al., 2008; GATHU; NJAGE, 2012; AGHKHANI et al., 2012).

The quality of the beans should be evaluated based on the beans' commercial, culinary and nutritional characteristics. Commercial quality can be defined as the type of bean, that is, color, shine, shape and size, which are the characteristics considered by breeders. Color and size are the first attributes evaluated by consumers, playing a decisive role in the acceptance of the product (BASSINELLO et al., 2003; GATHU; NJAGE, 2012).
Nutritional quality is related to the composition of the bean. According to Arvanitoyannis et al. (2007), beans can be a source of proteins, vitamins (thiamine, riboflavin, niacin, vitamin B6 and folic acid), dietary fiber (14-19\%) (particularly soluble fiber), minerals (Ca, Fe, $\mathrm{Cu}, \mathrm{Zn}, \mathrm{P}, \mathrm{K}$ and $\mathrm{Mg}$ ) and unsaturated fatty acids. Recent studies show that dietary fiber can protect against cardiovascular diseases, diabetes, obesity, colon cancer and other degenerative diseases.

The culinary quality of beans is as decisive as the commercial quality for future usage of a new cultivar. Culinary characteristics desired by consumers are quick hydration, low cooking time, production of thick broth, pleasant flavor, soft texture, thin skin, color stability and moderately cracked beans. The integrity of the beans after cooking is important for industrial application (BASSINELLO et al., 2003; AGHKHANI et al., 2012; GATHU; NJAGE, 2012).

According to Gathu and Njage (2012) and Hosfield et al. (1984), beans with softer texture have a shorter cooking time, making them more acceptable by the consumer, since the beans become more palatable. In addition, at an industrial scale, a bean with a short cooking time represents less expense to obtain the final product (cooked). The authors also report that beans that have a thinner outer skin are more easily hydrated during maceration, which in turn presents a shorter cooking time, as the water favors the transfer of heat to the inside of the beans, facilitating the cooking.

For Amir et al. (2007); Mkanda et al. (2007); González et al. (2006); Shimelis and Rakshit (2005) and Hosfield et al. (1984), the study of the chemical and physical characteristics of beans is important because they can influence the beans' culinary properties and the consumer's preferred bean of choice (CASTELLANOS et al., 1997). According to Rios et al. (2002), Brazilian consumers prefer freshly harvested beans, due to their softer texture, lighter coloring and shorter cooking time. 
As such, this study aimed to investigate some physical and chemical characteristics of seven varieties of beans grown in southeastern Brazil, sold nationally and internationally.

\section{Material and Methods}

\section{Samples}

The bean varieties studied here are commercialized in the Southern and southeastern regions of Brazil, and were provided by the Paraná Agronomic Institute (IAPAR). The Carioca, Saracura, IAPAR 81, Pérola, Colibri, IAPAR 31, Juriti bean varieties were harvested in December, 2004. After harvesting, the beans were stored in silos at room temperature for about 10 days until they reached around $12 \%$ moisture content. They were then maintained in a cold chamber at $4^{\circ} \mathrm{C}$ in the Food Technology laboratory of UEL until analyzed (LIU et al., 1992). The beans were cultivated in soil classified as purple dystrophic latosol (rich in aluminum) in the city of Pato Branco, PR, Brazil (latitude $26^{\circ} 11^{\prime} \mathrm{S}$, longitude $52^{\circ} 42^{\prime} \mathrm{W}$ and 740 meters in height).

\section{Methods}

The tests described below were carried out on all of the bean varieties.

\section{Bean size}

The average size of the raw beans of each variety was established according to the weight in grams of 100 units according to Zirmmermann et al. (1988) as: very small beans $<20 \mathrm{~g}$; small, 20 to 30 $\mathrm{g}$; average, 30 to $40 \mathrm{~g}$; normal, 40 to $50 \mathrm{~g}$ and big $>60$ g.

\section{Evaluation of bean color}

The color parameters, Luminance ( $\left.\mathrm{L}^{*}\right)$, red green component $\left(\mathrm{a}^{*}\right)$ and yellow - blue component (b*), of the beans were determined using a Byk Gardner colorimeter (model 45/0) with the following specifications: CIE illuminant D65 and $10^{\circ}$ standard observer. The raw beans were placed in a Petri dish, and measurements were taken at five points on the dish (top, bottom, right, left and middle). The measurements were carried out in triplicate, and the values for hue $\left(\mathrm{H}^{*}\right)$ were determined using the equation $\mathrm{H}^{*}=$ [arctang $\left.\left(\mathrm{b}^{*} / \mathrm{a}^{*}\right)\right]$.

\section{Equation: $\mathbf{H}^{*}=\left[\operatorname{arctang}\left(\mathrm{b}^{*} / \mathbf{a}^{*}\right)\right]$}

\section{Measurement of hardness}

The hardness of the raw beans was determined in Newtons (N) using a TA-XT2 Texture Analyzer (Texture Technologies Corp., White Plains). The raw beans, randomly selected, were subjected to compression at a constant speed of $2.0 \mathrm{~mm} / \mathrm{sec}$, the compression being carried out at $70 \%$ of the initial height, using an aluminum cylinder (P25L with a $2.5 \mathrm{~cm}$ diameter). Ten measurements were made in each replication of the experiment, where each measurement was made on a different individual bean.

\section{Bean water absorption during maceration}

The water absorption of the beans was determined according to $\mathrm{Lu}$ and Chang (1996) $100 \mathrm{~g}$ of beans were soaked in distilled water for 16 hours at room temperature at a ratio of 1:5 $\left(\mathrm{p} \mathrm{v}^{-1}\right)$ beans: water. After this period, the difference in weight of the bean was measured, and the level of hydration expressed as grams of water absorbed by $100 \mathrm{~g}$ of sample. The test was carried out in triplicate.

\section{Measurement of cooking time}

After macerating the beans in distilled water for 16 hours at room temperature, the cooking time was determined in adapted Mattson equipment. The test was carried out in triplicate with 16 measurements each (JACKSON; VARRIANO-MARSTON, 1981). 


\section{Integrity of beans after cooking}

After macerating the beans in distilled water for 16 hours at room temperature, the beans were placed in glass jars, covered and cooked in a water bath at $100^{\circ} \mathrm{C}$ for one hour, after which the percentage of beans that remained intact was determined (PLHAK et al., 1989; GARCIA-VELA; STANLEY, 1989). The tests were performed in triplicate.

\section{Proximate composition}

The raw beans were analyzed for content of moisture, protein, lipids and ash according to the methodology described in the AACC (1995). The total carbohydrates were obtained by difference. The results were expressed in grams of constituent $/ 100 \mathrm{~g}$ of sample.

\section{Mineral Content}

For analysis of minerals $\mathrm{P}, \mathrm{K}, \mathrm{Ca}, \mathrm{N}, \mathrm{Mg}, \mathrm{Cu}$, $\mathrm{Zn}, \mathrm{B}, \mathrm{Fe}$ and $\mathrm{Mn}$, the raw samples were digested in nitric perchloric acid (3:1 mixture of $65 \%$ nitric acid and $72 \%$ perchloric acid). After proper dilution, the reading was performed by plasma emission spectrometry in a Plasma ICAP 61E device (Thermo Jarrel Ash Corporation). The results of minerals $\mathrm{P}, \mathrm{K}, \mathrm{Ca}, \mathrm{N}$, and $\mathrm{Mg}$ were expressed as $\mathrm{g} \mathrm{kg}^{-1}$ of sample, and those of minerals $\mathrm{Cu}, \mathrm{Zn}, \mathrm{B}, \mathrm{Fe}$ and $\mathrm{Mn}$ as $\mathrm{mg} \mathrm{kg}^{-1}$ of sample, all performed in triplicate.

\section{Experimental design and statistical analysis}

The data from the experiments are presented as the mean \pm standard error mean (SEM), and were analyzes a one-way analysis of variance (ANOVA), with the differences analyzed by the Tukey at $\mathrm{p}<0.05$ (version 9.2; SAS Institute, Inc., Cary, NC, USA) (SAS, 1996).

\section{Results and Discussion}

According to the classification of size adopted by Zirmmermann et al. (1988), the beans studied were considered small, except the beans from the IAPAR 31 variety, which were classified as very small. The color parameters $\mathrm{L}^{*}, \mathrm{a}^{*}, \mathrm{~b}^{*}$ and $\mathrm{H}^{*}$ are shown in Table 1 . The beans from the IAPAR 31 variety have a striped surface, a peculiar characteristic in comparison to the other varieties.

Table 1. Color parameters $\left(\mathrm{L}^{*}, \mathrm{a}^{*}, \mathrm{~b}^{*}\right.$ and $\mathrm{H}^{*}$ ) and raw bean size of varieties Carioca, IAPAR 81, Saracura Juriti, Pérola, Colibri and IAPAR $31^{1,2}$.

\begin{tabular}{lccccc}
\hline \multicolumn{1}{c}{ Varieties } & $\mathbf{L}^{*}$ & $\mathbf{a}^{*}$ & $\mathbf{b}^{*}$ & Hue $\left(\mathbf{H}^{*}\right)$ & Bean Size \\
\hline Carioca & $41,29 \pm 1,17^{\mathrm{b}}$ & $12,17 \pm 0,52^{\mathrm{a}}$ & $18,97 \pm 0,92^{\mathrm{a}}$ & $57,22 \pm 0,29^{\mathrm{b}}$ & Small \\
IAPAR 81 & $48,6 \pm 0,58^{\mathrm{a}}$ & $9,72 \pm 0,03^{\mathrm{b}}$ & $18,76 \pm 0,74^{\mathrm{ab}}$ & $62,39 \pm 0,81^{\mathrm{a}}$ & Small \\
Saracura & $48,90 \pm 2,12^{\mathrm{a}}$ & $9,46 \pm 0,47^{\mathrm{b}}$ & $19,21 \pm 0,26^{\mathrm{a}}$ & $63,63 \pm 1,08^{\mathrm{a}}$ & Small \\
Juriti & $49,44 \pm 1,19^{\mathrm{a}}$ & $9,96 \pm 0,85^{\mathrm{b}}$ & $19,52 \pm 0,04^{\mathrm{a}}$ & $62,91 \pm 1,88^{\mathrm{a}}$ & Small \\
Pérola & $49,63 \pm 1,46^{\mathrm{a}}$ & $9,85 \pm 0,35^{\mathrm{b}}$ & $18,88 \pm 0,45^{\mathrm{a}}$ & $62,35 \pm 0,75^{\mathrm{a}}$ & Small \\
Colibri & $48,55 \pm 2,64^{\mathrm{a}}$ & $9,03 \pm 0,36^{\mathrm{b}}$ & $17,48 \pm 2,48^{\mathrm{b}}$ & $61,27 \pm 1,83^{\mathrm{a}}$ & Small \\
IAPAR 31 & $51,27 \pm 0,08^{\mathrm{a}}$ & $9,48 \pm 0,38^{\mathrm{b}}$ & $19,44 \pm 0,66^{\mathrm{a}}$ & $63,67 \pm 1,43^{\mathrm{a}}$ & Very small \\
\hline
\end{tabular}

$\mathrm{L}^{*}=$ Luminance $\left(0=\right.$ black; $100=$ white); $\mathrm{a}^{*}$ (-=green; +=red); b*(-=blue; +=yellow)

${ }^{1}$ Average of three replications with five measurements in each replication \pm standard deviation

${ }^{2}$ Averages accompanied by the same letter in the same column do not differ significantly among themselves at $\mathrm{p} £ 0.05$ 
The beans from varieties IAPAR 81, Saracura, Juriti, Pérola, Colibri and IAPAR 31 showed values of L* similar to and greater than the beans from the Carioca variety, indicating that the Carioca variety has darker beans ( $£ £ 0.05)$. Similar behavior was observed for $\mathrm{a}^{*}$ values (red-green component).

In regards to parameter $b^{*}$ (yellow - blue component), the beans from variety Colibri showed the smallest value, being the most yellow $(p<0.05)$. However, there was no difference in the value obtained for the beans from the IAPAR 81 variety. The IAPAR 81 variety also did not differ from the other varieties, which were similar to each other, having greater values since they were more yellow ( $>0.05)$.

There was no difference among the beans from the Carioca, IAPAR 81, Saracura, Juriti, Pérola and IAPAR 31 varieties for hue $\left(\mathrm{H}^{*}\right)$, which were more yellow and had higher values than those of the Carioca variety, which had redder beans $(\mathrm{p}<0.05)$.
Factors that can influence the color and size of a bean are genotype, variety, planting period, chemical composition of the beans and storage time, among others (MKANDA et al., 2007). According to Rios et al. (2002), consumers prefer lighter colored beans, because they relate darker color to old, hard beans that require more time to cook, generating increased energy expenditure. The beans from the Carioca variety were darker according to parameter $\mathrm{L}^{*}($ Luminance, where $0=$ black; white $=100)$, the luminance value of which was 41.29 , lower than the beans of the other varieties.

The hardness measured in raw beans (Table 2) indicated that the IAPAR 81 variety had the hardest beans, and the Pérola variety had the softest. These differences are due to the factor of variety. Furthermore, the texture can be influenced by the location and production period, weather and storage conditions, chemical composition and other factors (KIGEL, 1999).

Table 2. Hardness of raw beans, degree of hydration during maceration, cooking time and integrity of cooked beans from varieties Carioca, IAPAR 81, Saracura, Juriti, Pérola, Colibri and IAPAR $31^{1}$

\begin{tabular}{|c|c|c|c|c|}
\hline Varieties & Hardness (Newton) ${ }^{2}$ & $\begin{array}{c}\text { Hydration during } \\
\text { maceration }(\mathrm{g} / \mathbf{1 0 0 g})^{3}\end{array}$ & $\begin{array}{c}\text { Cooking time } \\
\text { (minutes) }^{3}\end{array}$ & $\begin{array}{c}\text { \% whole beans after } \\
\text { cooking }\end{array}$ \\
\hline Carioca & $150,76 \pm 17,29^{\mathrm{b}}$ & $99,09 \pm 0,86^{\text {bc }}$ & $34,67 \pm 2,08^{\mathrm{bc}}$ & $64,38 \pm 10,80^{\mathrm{b}}$ \\
\hline IAPAR 81 & $175,25 \pm 15,68^{\mathrm{a}}$ & $102,24 \pm 1,94^{\mathrm{ab}}$ & $39,33 \pm 1,53^{\mathrm{ab}}$ & $82,16 \pm 2,99^{\mathrm{a}}$ \\
\hline Saracura & $149,14 \pm 22,97^{b}$ & $95,70 \pm 1,80^{\mathrm{c}}$ & $22,67 \pm 0,58^{\mathrm{d}}$ & $30,00 \pm 8,67^{\mathrm{c}}$ \\
\hline Juriti & $139,28 \pm 34,04^{\text {bc }}$ & $101,75 \pm 0,42^{\mathrm{ab}}$ & $43,67 \pm 4,93^{\mathrm{a}}$ & $55,28 \pm 2,78^{\mathrm{b}}$ \\
\hline Pérola & $95,79 \pm 29,54^{\mathrm{e}}$ & $106,77 \pm 1,85^{\mathrm{a}}$ & $43,67 \pm 1,53^{\mathrm{a}}$ & $82,16 \pm 5,85^{\mathrm{a}}$ \\
\hline Colibri & $120,74 \pm 28,20^{\mathrm{cd}}$ & $100,91 \pm 0,85^{\mathrm{bc}}$ & $42,67 \pm 2,73^{\mathrm{a}}$ & $94,91 \pm 2,02^{\mathrm{a}}$ \\
\hline IAPAR 31 & $113,23 \pm 19,38^{\mathrm{de}}$ & $104,36+3,81^{\mathrm{ab}}$ & $29,67 \pm 1,05^{\text {cd }}$ & $86,80 \pm 5,89^{\mathrm{a}}$ \\
\hline
\end{tabular}

${ }^{1}$ Averages accompanied by the same letter in the same column do not differ significantly at $\mathrm{p} £ 0,05$

${ }^{2}$ Average of three replication with 10 measurements in each replication \pm standard deviation.

${ }^{3}$ Average of three replications \pm standard deviation.

The results of water absorption during maceration, cooking time and integrity of cooked beans are presented in Table 2.

The water absorption of the seven varieties of

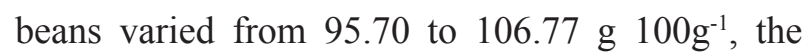
greatest value being that of the Pérola variety and the lowest, Saracura $(p<0.05)$. The Juriti, Pérola and Colibri varieties showed longer cooking time (average 43.33 minutes), and the Saracura variety showed the shortest time (22.67 minutes) $(\mathrm{p}<0.05)$. Regarding percentage of whole beans after cooking, there was a range from $30 \%$ (Saracura) to $86.50 \%$ (IAPAR 81, Pérola, Colibri and IAPAR 31).

The Saracura variety showed the lowest values of water absorption, cooking time and percentage of whole beans after cooking, while the Pérola variety 
showed the greatest values for these parameters $(p<0,05)$. However, no correlation was observed between these parameters; the beans that needed a longer cooking time simply had a tendency to remain whole after being cooked for an identical and predetermined amount of time as in the analyses of all of the varieties of beans.

Bean maceration is a procedure that aims to decrease the cooking time, as the water favors the transfer of heat, facilitating the cooking of the bean (SHIMELIS; RAKSHIT, 2005). It was expected that the greater the hydration during maceration, the more the cooking time would be reduced, but this result was not observed, being that other parameters can influence the cooking time, including chemical composition, skin hardness and storage time, among others (AGHKHANI et al., 2012). In the current work, it was not possible to correlate the amount of absorbed water during the maceration procedure to the cooking time. Furthermore, other factors might be influencing the process.

Mkanda et al. (2007) studied six bean varieties grown in different locations, and obtained hydration

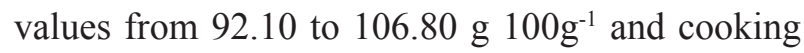
times that varied from 42.4 to 97.8 minutes.
According to the authors, the cooking time and texture of the beans can be influenced by many factors such as variety, growth site and storage conditions, as well as the physicochemical properties of the cotyledons and the skin of the beans.

Sefa-Dedeh et al. (1978) investigated the effect of maceration time and cooking conditions on the texture of the caupi bean. A hydration level of 105 $\mathrm{g}$ of water/100 $\mathrm{g}$ of beans was observed in a period of 18 hours. According to the authors, the amount of water absorbed per unit of weight increases with time of maceration, reaching equilibrium (104 $\mathrm{g}$ of water $100 \mathrm{~g}^{-1}$ ) after 12 hours of maceration. Even so, in the caupi bean, proteins, starch present in the cotyledons and anatomical characteristics such as the bean skin and size of the micropyle significantly influenced the total water absorbed. As reported by VELASCO-GONZÁLEZ et al. (2008) the amount of water absorbed by the beans was related to the contact surface area, larger the contact surface area promote higher water absorption. In addition, cracks in the husk and the protein content might contribute to higher water absorption. In this work, beans of the variety "pérola" presented the highest amount of water absorption as well as the highest protein content (Table 3).

Table 3. Proximate composition of bean varieties Carioca, IAPAR 81, Saracura, Juriti, Pérola, Colibri and IAPAR 31 1,2,3.

\begin{tabular}{lccccc}
\hline \multicolumn{1}{c}{ Varieties } & Moisture & Proteins & Lipids & Ash & Carbohydrates \\
\hline Carioca & $12,09 \pm 0,16^{\mathrm{d}}$ & $22,30 \pm 1,32^{\mathrm{b}}$ & $1,19 \pm 0,29^{\mathrm{b}}$ & $4,04 \pm 0,19^{\mathrm{a}}$ & $72,47^{\mathrm{a}} \pm 1,19^{\mathrm{a}}$ \\
IAPAR81 & $12,25 \pm 0,09^{\mathrm{d}}$ & $23,48 \pm 0,94^{\mathrm{ab}}$ & $1,81 \pm 0,29^{\mathrm{ab}}$ & $3,88 \pm 0,18^{\mathrm{ab}}$ & $70,83 \pm 0,77^{\mathrm{ab}}$ \\
Saracura & $13,28 \pm 0,22^{\mathrm{bc}}$ & $22,03 \pm 1,11^{\mathrm{b}}$ & $1,87 \pm 0,14^{\mathrm{ab}}$ & $4,00 \pm 0,10^{\mathrm{a}}$ & $72,10 \pm 1,08^{\mathrm{ab}}$ \\
Juriti & $12,52 \pm 0,39^{\mathrm{dc}}$ & $22,49 \pm 0,57^{\mathrm{ab}}$ & $1,99 \pm 0,54^{\mathrm{a}}$ & $4,05 \pm 0,12^{\mathrm{a}}$ & $71,4 \pm 0,90^{\mathrm{ab}}$ \\
Pérola & $13,51 \pm 0,11^{\mathrm{b}}$ & $24,76 \pm 0,77^{\mathrm{a}}$ & $1,47 \pm 0,14^{\mathrm{ab}}$ & $3,89 \pm 0,04^{\mathrm{ab}}$ & $69,89 \pm 0,95^{\mathrm{b}}$ \\
Colibri & $13,44 \pm 0,55^{\mathrm{b}}$ & $24,86+0,60^{\mathrm{a}}$ & $1,26 \pm 0,16^{\mathrm{ab}}$ & $3,76 \pm 0,09^{\mathrm{ab}}$ & $70,08 \pm 0,57^{\mathrm{ab}}$ \\
IAPAR31 & $14,47 \pm 0,20^{\mathrm{a}}$ & $24,23 \pm 0,52^{\mathrm{ab}}$ & $1,38 \pm 0,21^{\mathrm{ab}}$ & $3,66 \pm 0,07^{\mathrm{b}}$ & $70,73 \pm 0,47^{\mathrm{ab}}$ \\
\hline
\end{tabular}

${ }^{1}$ Average of three replications \pm standard deviation

${ }^{2}$ Averages accompanied by the same letter in the same column do not differ significantly at $\mathrm{p} £ 0,05$

${ }^{3}$ Results expressed on dry basis (d.b.), except for moisture, in $\mathrm{g} / 100 \mathrm{~g}$ of sample. 
Sefa-Dedeh and Stanley (1979) evaluated the water absorption of two bean species (Phaseolus vularis and Vigna unguiculata) and one variety of soy (Glycine max) during maceration. In 16 hours of maceration, the beans absorbed $110 \mathrm{~g}$ of water 100 $\mathrm{g}^{-1}$, while the soy absorbed $143 \mathrm{~g}$ of water $100 \mathrm{~g}^{-1}$ of sample, being that the values remained constant after this period which were higher to the values observed in this work. According to the authors, the soy absorbed a greater amount of water due to a higher content of protein, because proteins absorb more water than any other component in legumes.

Cooking times of 22.50 to 41.70 minutes were observed by Shimelis and Rakshit (2005) in eight varieties of common beans which were close to those values observed in this work. They also observed a negative correlation between the calcium levels in the beans and the water absorption capacity during maceration, cooking time and hardness of cooked beans. However, Saikia et al. (1999) found a cooking time of 50 to 57 minutes in four strains of Vigna umbellata beans which were higher than those observed in the grains studied in this work.

The content of moisture, protein, lipids, ash and carbohydrates of the seven bean varieties studied can be found in Table 3 .

The varieties studied had protein content ranging

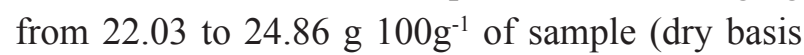
or d.b.) and were within the range (19.61 to 36.28 g $100 \mathrm{~g}^{-1}$ ) found in literature for common beans (SHIMELIS; RAKSHIT, 2005; COSTA et al., 2006; MARCONI et al., 2000; AMIR et al., 2007; MESQUITA et al., 2007).

Different levels of lipid content were observed in $\mathrm{g} 100 \mathrm{~g}^{-1}$ of sample (d.b.), being that the greatest difference occurred between the Carioca (1.19) and Juriti (1.99) varieties $(\mathrm{p}<0,05)$. The results observed are similar to the values found by Shimelis and Rakshit (2005) (0.67 to 1.20), less than the values (2.49 to 2.52) found by Costa et al. (2006) and greater than the values ( 0.46 to 0.52 ) found by Saikia et al. (1999). As reported by Segundo Rivera et al.
(2013) the composition of the bean variety maybe influenced by its genotype, local (soil composition) and period of cultivation. Those differences found in this work related to the carbohydrates and fat contents, probably were associated to genotypes characteristics of each variety, since they were cultivated in the same local and year period.

The ash content, in $\mathrm{g} / 100 \mathrm{~g}$ of sample (d.b.), ranged from 3.66 (IAPAR 31) to 4.05 (Juriti). The values observed are similar to those found by Shimelis and Rakshit (2005) (2.86 to $4.26{\mathrm{~g} 100 \mathrm{~g}^{-}}^{-}$

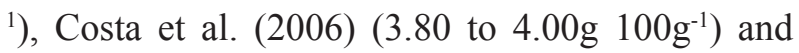

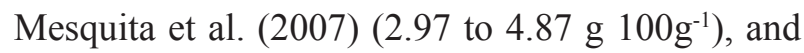
lower than the values found by Saikia et al. (1999)

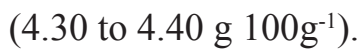

The average carbohydrate content was between 69.89 (Pérola) to $72.47100 \mathrm{~g}^{-1}$ of sample (d.b.) (Saracura), being higher than the values cited by Shimelis and Rakshit (2005) (62.05 to $65.08{\mathrm{~g} 100 \mathrm{~g}^{-}}^{-}$

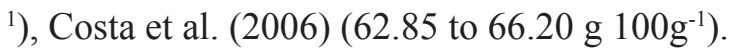

The mineral concentrations in the bean varieties studied are presented in Tables 4 and 5 .

The varieties did not show differences regarding concentrations of phosphorus, zinc and boron. The average phosphorus content was $4.48 \mathrm{~g} \mathrm{~kg}^{-1}$ (d.b.), being that Mesquita et al. (2007) found content levels ranging from 4.5 to $7.2 \mathrm{~g} \mathrm{~kg}^{-1}$ of dry material in 21 Brazilian strains of beans (Phaseolus vulgaris L.), while Shimelis and Rakshit (2005) found values from 0.15 to $0.17 \mathrm{~g} \mathrm{~kg}^{-1}$ (d.b.) in eight varieties of haricot beans (Phaseolus vulgaris L.) grown in Ethiopia. The average zinc content was $28.21 \mathrm{mg}$ $\mathrm{kg}^{-1}$ (d.b.), similar to that found by Shimelis and Rakshit (2005) (15.39 to $28.22 \mathrm{mg} \mathrm{kg}^{-1}$, d.b.) and Ribeiro et al. (2008) (30.03 $\mathrm{mg} \mathrm{kg}^{-1}$, d.b.) and less than that reported (36.9 to $69.9 \mathrm{mg} \mathrm{kg}^{-1}$, d.b.) by Mesquita et al. (2007).

Differences were observed in the potassium concentrations, in $\mathrm{g} \mathrm{kg}^{-1}$ of sample (d.b.), between varieties Saracura (13.7) and IAPAR 31 (11.20) $(\mathrm{p}<0.05)$. The magnesium concentration ranged from 1.53 (Colibri and Juriti varieties) to 1.83 
(Cariosa, Saracura and Pérola varieties). Mesquita et al. (2007) found potassium levels that ranged from 15.1 to 24.8 and magnesium levels from 1.8 to 3.4. Regarding calcium, the Juriti variety had the lowest content in comparison to the others, except for the IAPAR 31 variety $(\mathrm{p}<0.05)$. Shimelis and Rakshit (2005) found similar values (0.73 to 1.92), while Mesquita et al. (2007) found values ranging from 0.3 to 2.8 .

Table 4. Mineral composition ( $\mathrm{P}, \mathrm{K}, \mathrm{Ca}, \mathrm{N}$ and $\mathrm{Mg}$ ) of bean varieties Carioca, IAPAR 81, Saracura, Juriti, Pérola, Colibri and IAPAR $31^{1,2,3}$.

\begin{tabular}{lcccccc}
\hline & Variety & \multicolumn{4}{c}{ Minerals $^{\mathbf{1 , 2 , 3}}$} \\
\cline { 2 - 7 } & $\mathbf{P}$ & $\mathbf{K}$ & $\mathbf{C a}$ & $\mathbf{N}$ & $\mathbf{M g}$ & $\mathbf{S}$ \\
\hline Carioca & $4,56 \pm 0,13^{\mathrm{a}}$ & $13,33 \pm 0,63^{\mathrm{ab}}$ & $1,74 \pm 0,20^{\mathrm{a}}$ & $31,97 \pm 1,53^{\mathrm{abc}}$ & $1,83 \pm 0,03^{\mathrm{a}}$ & $2,14 \pm 0,07^{\mathrm{ab}}$ \\
IAPAR 81 & $4,75 \pm 0,30^{\mathrm{a}}$ & $12,30 \pm 1,21^{\mathrm{ab}}$ & $1,52 \pm 0,18^{\mathrm{a}}$ & $29,55 \pm 0,35^{\mathrm{bc}}$ & $1,69 \pm 0,11^{\mathrm{ab}}$ & $2,09 \pm 0,08^{\mathrm{ab}}$ \\
Saracura & $4,29 \pm 0,18^{\mathrm{a}}$ & $13,70 \pm 0,0^{\mathrm{a}}$ & $1,67 \pm 0,21^{\mathrm{a}}$ & $29,10 \pm 1,10^{\mathrm{c}}$ & $1,80 \pm 0,00^{\mathrm{a}}$ & $2,02 \pm 0,07 \mathrm{ab}$ \\
Juriti & $4,65 \pm 027^{\mathrm{a}}$ & $12,97 \pm 0,63^{\mathrm{ab}}$ & $0,88 \pm 0,85^{\mathrm{b}}$ & $29,60 \pm 1,19^{\mathrm{bc}}$ & $1,54 \pm 0,08^{\mathrm{b}}$ & $1,97 \pm 0,06 \mathrm{~b}$ \\
Pérola & $4,35 \pm 0,14^{\mathrm{a}}$ & $12,60 \pm 0,57^{\mathrm{ab}}$ & $1,44 \pm 0,08^{\mathrm{a}}$ & $34,54 \pm 0,48^{\mathrm{a}}$ & $1,86 \pm 0,08^{\mathrm{a}}$ & $2,32 \pm 0,09^{\mathrm{a}}$ \\
Colibri & $4,30 \pm 0,32^{\mathrm{a}}$ & $12,96 \pm 0,63^{\mathrm{ab}}$ & $1,65 \pm 0,32^{\mathrm{a}}$ & $33,47 \pm 2,07^{\mathrm{a}}$ & $1,53 \pm 0,09^{\mathrm{b}}$ & $2,08 \pm 0,09^{\mathrm{ab}}$ \\
IAPAR 31 & $4,49 \pm 0,28^{\mathrm{a}}$ & $11,20 \pm 1,21^{\mathrm{b}}$ & $1,24 \pm 0,15^{\mathrm{ab}}$ & $32,72 \pm 1,32^{\mathrm{ab}}$ & $1,72 \pm 0,10^{\mathrm{ab}}$ & $2,24 \pm 0,11^{\mathrm{ab}}$ \\
\hline
\end{tabular}

${ }^{1}$ Average of three replications \pm standard deviation

${ }^{2}$ Averages accompanied by the same letter in the same column do not differ significantly at $\mathrm{p} £ 0,05$

${ }^{3}$ Results expressed in $\mathrm{g} / \mathrm{kg}$ of sample (d.b).

Table 5. Mineral composition $(\mathrm{Cu}, \mathrm{Zn}, \mathrm{B}, \mathrm{Fe}$ and $\mathrm{Mn})$ of bean varieties Carioca, IAPAR 81, Saracura, Juriti, Pérola, Colibri and IAPAR $31^{1,2,3}$.

\begin{tabular}{|c|c|c|c|c|c|}
\hline \multicolumn{3}{|c|}{ Variety } & \multicolumn{3}{|c|}{ Minerals ${ }^{1,2,3}$} \\
\hline & $\mathrm{Cu}$ & Zn & B & $\mathrm{Fe}$ & Mn \\
\hline Carioca & $8,23 \pm 0,11^{\mathrm{bc}}$ & $27,10 \pm 3,96^{\mathrm{a}}$ & $12,43 \pm 0,96^{\mathrm{a}}$ & $66,30 \pm 1,83^{\mathrm{ab}}$ & $14,73 \pm 1,05^{\mathrm{a}}$ \\
\hline IAPAR 81 & $8,67 \pm 0,35^{\mathrm{b}}$ & $27,10 \pm 3,90^{\mathrm{a}}$ & $12,60 \pm 2,68^{a}$ & $66,55 \pm 2,47^{\mathrm{ab}}$ & $11,83 \pm 0,50^{\mathrm{b}}$ \\
\hline Saracura & $6,36 \pm 0,46^{\mathrm{d}}$ & $25,60 \pm 2,90^{\mathrm{a}}$ & $12,43 \pm 1,52^{\mathrm{a}}$ & $74,05 \pm 2,33^{\mathrm{a}}$ & $15,03 \pm 0,76^{\mathrm{a}}$ \\
\hline Juriti & $8,37 \pm 0,21^{b c}$ & $25,50 \pm 3,51^{\mathrm{a}}$ & $12,70 \pm 2,26^{\mathrm{a}}$ & $62,25 \pm 1,98^{b}$ & $13,30 \pm 0,46^{\mathrm{ab}}$ \\
\hline Pérola & $10,33 \pm 0,15^{\mathrm{a}}$ & $31,23 \pm 4,70^{\mathrm{a}}$ & $10,07 \pm 1,30^{\mathrm{a}}$ & $73,45 \pm 2,33^{\mathrm{a}}$ & $14,93 \pm 0,66^{\mathrm{a}}$ \\
\hline Colibri & $7,73 \pm 0,29^{c}$ & $30,60 \pm 4,15^{\mathrm{a}}$ & $8,70 \pm 1,11^{\mathrm{a}}$ & $62,50 \pm 2,61^{\mathrm{b}}$ & $14,77 \pm 0,66^{\mathrm{a}}$ \\
\hline IAPAR 31 & $5,97 \pm 0,51^{\mathrm{d}}$ & $30,70 \pm 4,00^{\mathrm{a}}$ & $10,17 \pm 1,62^{\mathrm{a}}$ & $69,20 \pm 3,11^{\mathrm{ab}}$ & $13,20 \pm 0,72^{\mathrm{ab}}$ \\
\hline
\end{tabular}

${ }^{1}$ Average of three replications \pm standard deviation

${ }^{2}$ Averages accompanied by the same letter in the same column do not differ significantly at $\mathrm{p} £ 0,05$

${ }^{3}$ Results expressed in $\mathrm{mg} / \mathrm{kg}$ of sample (d.b).

The concentration, in $\mathrm{mg} \mathrm{kg}^{-1}$ of sample (d.b.), of copper ranged from 6.36 (Saracura) to 10.33 (Pérola). For manganese, the IAPAR 81 variety showed a lower value (11.83) than that of the Carioca, Saracura, Pérola and Colibri varieties (average 14.89). For Mesquita et al. (2007), the values ranged from 11.37 to 17.73 for copper and from 14.93 to 28.90 for manganese. Ribeiro et al. (2008) found an average content of 18.8 for manganese and a range of 6.0 to 9.8 for copper.

The iron content in the beans from the Saracura and Pérola varieties was greater than that of the IAPAR 31 variety. Literature reports values ranging from 60 to $130 \mathrm{mg} \mathrm{kg}^{-1}$ (d.b.) (SHIMELIS; RAKSHIT, 2005; MESQUITA et al., 2007; RIBEIRO et al., 2008). 
In addition to the nutritional aspect, knowledge of the chemical composition of beans is also important for the culinary characteristics of the beans. Paredes-López et al. (1989), Lu and Chang (1996) and Lange and Labuschagne (2001) related bean hardness, cooking time and water absorption capacity during maceration to the amount of salts, more specifically calcium and magnesium, present in the bean. The authors observed that beans with high content of these salts are harder, both in raw and cooked form. Kigel (1999) also observed that beans grown in soils rich in calcium and magnesium and with elevated average annual temperatures (15$24^{\circ} \mathrm{C}$ ) had higher cooking times and hardness in comparison to beans from the same variety grown in locations with lower temperatures $\left(11\right.$ to $\left.18^{\circ} \mathrm{C}\right)$ and soils with low levels of magnesium and calcium. However, in this study, no relation between bean mineral composition and hardness of raw beans, water absorption, cooking time and percentage of whole cooked beans was observed.

It is in the interest of researchers, food industries and consumers to use bean varieties that are rich in nutrients, have lower cooking time and have a higher percentage of whole beans after cooking, because they will lose less quantity of solids (nutrients). However, many consumers prefer beans that are well cooked, soft and falling apart, with very thick broth (SHIMELIS; RAKSHIT, 2005; RIOS et al., 2002).

\section{Conclusions}

The Carioca, IAPAR 81, Saracura, Juriti, Pérola, Colibri and IAPAR 31 varieties showed differences regarding chemical and physical characteristics. Among these varieties, Saracura stood out for having high mineral content, the lowest cooking time, resulting in lower energy consumption, and greater integrity of beans after cooking. Despite having the lowest protein content, even so it is within the range found in literature on beans. As such, the Saracura variety can be recommended for domestic use and for processing in the food industry.

\section{Acknowledgements}

To the Agronomical Institute of Paraná (IAPAR) for performing the mineral analyses.

\section{References}

AGHKHANI, M. H.; ASHTIANI, S. H. M.; MOTIE, J. B.; ABBASPOUR-FARD, M. H. Physical properties of Christmas Lima bean at different moisture content. International Agrophysis, Mashhad, v. 26, n. 4, p. 341346, 2012.

AIKIA, P.; SARKAR, C. R.; BORUA, I. Chemical composition, antinutritional factors and effect of cooking on nutritional quality of rice bean (Vigna umbellata; Thunb; Ohwi e Ohashi). Food Chemistry, Barking, v. 67, n. 3, p. 347-352, 1999.

AMERICAN ASSOCIATION OF CEREAL CHEMIST - AACC. Approved methods of the american association of cereal chemists. Saint Paul: AACC, 1995. v. 2. 1200 p.

AMIR, Y.; HAENNI, A. L.; YOUYOU, A. Physical and biochemical differences in the composition of the seeds of Algerian leguminous crops. Journal of Food Composition and Analysis, Paris, v. 20, n. 6, p. 466-471, 2007.

ANTON, A. A.; ROSS, K. A.; BETA, T.; FULCHER, R. G.; ARNTFIELD, S. D. Effect of pre-dehulling treatments on some nutritional and physical properties of navy and pinto beans (Phaselus vulgaris L.). Food Science and Technology, Winnipeg, v. 41, n. 5, p. 771778, 2008.

ARVANITOYANNIS, I. S.; MAVROMATIS, A.; RODIATIS, A.; GOULAS, C. Physicochemical and sensory analysis of dry bean landraces in conjunction wtih multivariate analysis: an exploraty approach. International Journal of Food Science and Technology, Volos Hellas, v. 42, n. 7, p. 819-826, 2007.

BASSINELLO, P. Z.; COBUCCI, R. M. A.; UCHÔA, V. G.; MELO, L. C.; DEL PELOSO, M. J. Aceitabilidade de três cultivares de feijoeiro comum. Comunicado Técnico, Santo Antonio de Goiás, v. 66, n. 2, p. 1-2, 2003.

CASTELLANOS, J. Z.; MALDONADO, H. G.; JIMENEZ,A.; MEIJA, C.; RAMOS, J.D. J.; GALLEGOS, J. A. A.; HOYOS, G.; SALINAS, E. L.; EGUIARTE, D. G.; PERES, R. S.; ACUNA, J. G.; VILLALOBOS, J. A. M.; HERNANDEZ, P. F. Preferential habits of consumers of common bean (Phaseolus vulgaris L.) in Mexico. Archivos Latino americanos de Nutrición, Celaya, v. 47, n. 2, p. 163-167, 1997. 
COMPANHIA NACIONAL DE ABASTECIMENTO - CONAB. Produção de brasileira de feijão. Brasília: Sumac, 2008. Disponível em: <http://www.conab.gov. br>. Acesso em: 22 abr. 2008.

COSTA, E. G. A.; MONICI, K. S. Q.; REIS, S. M. P. M.; OLIVEIRA, A. C. Chemical composition, dietary fiber and resistant starch contents of raw and cooked pea, common bean, chickpea and lentil legumes. Food Chemistry, Campinas, v. 94, n. 3, p. 327-330, 2006.

GARCIA-VELA, L. A.; STANLEY, D. W. Water-holding capacity in hard-to-cook beans (Phaseolus vulgaris): effect of $\mathrm{pH}$ and ionic strength. Journal of Food Science, Chicago, v. 54, n. 4, p. 1080-1081, 1989.

GATHU, W. E.; NJAGE, P. M. K. Physical characterization of new advanced drought tolerant common bean (Phaseolus vulgaris) lines for canning quality. American Journal of Food Technology, Nairob, v. 7, n. 2, p. 22-28, 2012.

GONZÁlez, A. M.; MONTEAGUdO, A. B.; CASQUERO, P. A.; DE RON, A. M.; SANTALLA, M. Genetic variation and environment effects on agronomical and commercial quality traits in the main European market classes of dry bean. Field Crops Research, Pontevedra, v. 95, n. 2-3, p. 336-347, 2006.

GRAHAM, P. H.; RANALLI, P. Common bean. Field Crops Research, Minnesota, v. 53, n. 1-3, 131-146, 1997.

HOSFIELD, G. L.; GHANDERI, A.; UEBERSAX, M. A. A factor analysis of yield and sensory and physicochemical data test used to measure culinary quality in dry edible beans. Canadian Journal Plant Science, Michigan, v. 64, n. 2, p. 285-293, 1984.

JACKSON, G. M.; VARRIANO-MARSTON, E. M. Hard-to-cook phenomenon in beans: effects of accelerated storage on water absorption and cooking time. Journal of Food Science, Manhattan, v. 46, n. 2, p. 799-803, 1981.

KIGEL, J. Culinary and nutritional quality of Phaseolus vulgaris seeds as affected by environmental factors. Biotechnology Agronomic Society Environment, Guembloux, v. 3, n. 4, p. 205-209, 1999.

LANGE, A.; LABUSCHAGNE, M. Multivariate assessment of canning quality, chemical characteristics and yield of small white canning beans (Phaseolus vulgaris L.) in South Africa. Journal of the Science of Food and Agriculture, Oxford, v. 81, n. 1, p. 30-35, 2001.

LIU, K.; PHILIPS, R. D.; HUNG, Y. C.; SHEWFELT, R. L.; McWATTER, K. H. Hard-to-cook defect in cowpeas: Storage-induced and treatment-induced development. Journal of Food Science, Vancouver, v. 57, n. 5, p. 11551160, 1992.
LU, W.; CHANG, K. C. Correlations between chemical composition and canning quality attributes of navy bean (Phaseolus vulgaris L.). Cereal Chemistry, Manhattan, v. 73 , n. 6, p. 785-787, 1996.

MARCONI, E.; RUGGERI, S.; CAPPELLONI, M.; LEONARDI, D.; CARNOVALE, E. Physicochemical, nutritional and microestrutural characteristics of chickpeas (Cicerarietinum L,) and common beans (Phaseolus vulgaris L.) following microwave cooking. Journal Agricultural of Food Chemistry, Arkansas, v. 48, n. 12, p. 5986-5994, 2000.

MESQUITA, F. R.; CORRÊA, A. D.; ABREU, C. M. P.; LIMA, R. A. Z.; ABREU, A. F. B. Linhagens de feijão (PhaseolusVulgaris L.): composição química e digestibilidade protéica. Ciência e Agrotecnologia, Lavras, v. 31, n. 4, p. 1114-1121, 2007.

MKANDA, A. V.; MINNAAR, A.; DE KOCK, H. L. Relating consumer preferences to sensory and physicochemical properties of dry beans (Phaseolus vulgaris). Journal of the Science of Food and Agriculture, Oxford, v. 87, n. 12, p. 2868-2879, 2007.

MONTOYA, C. A.; LETERME, P.; VICTORIA, N. F.; TORO, O.; SOUFFRANT, W. B.; BEEBE, S.; LALLES, J. P. Susceptibility of phaseolin to in vitro proteolysis is highly variable across common bean varieties (Phaseolus vulgaris). Journal Agricultural of Food Chemistry, v. 56, n. 6, p. 2183-2191, 2008.

PAREDES-LÓPEZ， O.; REYES-MORENO， C.; MONTES-RIVERA, R.; CARABEZ-TREJO, A. Hardto-cook phenomenon in common beans influence of growing location and hardening procedures. International Journal of Food Science and Technology, Buenos Aires, v. 24, n. 5, p. 535-542, 1989.

PLHAK, L. C.; CALDWELL, K. B.; STANLEY, D. W. Comparison of methods used to characterize water imbition in hard-to-cook beans. Journal of Food Science, Vancouver, v. 54, n. 2, p. 326-328, 1989.

RIBEIRO, N. D.; JOST, E.; TAIGUER, C. T.; MAZIERO, S. M.; POERSCH, N. L. Composição de microminerais em cultivares de feijão e aplicações para o melhoramento genético. Bragantia, Campinas, v. 67, n. 2, p. 267-273, 2008.

RIOS, A. O.; ABREU, C. M. P.; CORRÊA, A. D. Efeitos da época de colheita e o tempo de armazenamento no escurecimento do tegumento de feijão (Phaseolus vulgaris L.). Ciência e Agrotecnologia, Lavras, v. 26, n. 3, p. 550-558, 2002.

RIVERA, A.; FENERO, D.; ALMIRALL, A.; FERREIRA， J. J.; SIMO, J.; MARÇAL, P.; DEL CASTILLO, R. R.; CASAN, F. Variability in sensory 
attributes in common bean (Phaseolus vulgaris L.): a first survey in the Iberian secondary diversity center. Genetic Resources and Crop Evolution, Netherlands, v. 20, n. 2, p. 1885-1898, 2013.

STATISTICAL ANALYSIS SYSTEM INSTITUTE SAS. SAS INSTITUTE INC, SAS users' guide: Statistics, version 6,12. Cary: NC, USA, 1996.

SEFA-DEDEH, S.; STANLEY, D. W. Textural implications of the microstructure of legumes. Food Technology, Chicago, v. 79, n. 10, p. 77-80, 1979.

SEFA-DEDEH, S.; STANLEY, D. W.; VOISEY, P. W. Effects of soaking time and cooking conditions on texture and microstructure of cowpeas (Vigna unguiculata). Food Technology, Chicago, v. 79, n. 6, p. 833-839, 1978.

SHIMELIS, E. A.; RAKSHIT, S. K. Proximate composition and physico-chemical properties of improved dry bean (Phaseolus vulgaris L,) varieties grown in Ethiopia. Journal of Food Science, Bangkok, v. 38, n. 4, p. 331-338, 2005.
TOLEDO, T. C. F.; CANNIATTI-BRAZACA, S. G. Avaliação química e nutricional do feijão carioca (Phaseolus vulgaris L.) cozido por diferentes métodos. Ciência e Tecnologia de Alimentos, Campinas, v. 28, n. 2, p. 355-360, 2008.

VELASCO-GONZALES, O.; ECHAVARRÍAALMEIDA, P. A.; MARTÍN-MARTINEZ, E. S. Effect of bean size on the physicochemical properties of different bean varieties (Phaseolus vulgaris). Acta Alimentaria, Budapest, v. 37, v. 37, n. 3, p. 323-336, 2008.

ZIRMMERMANN, M. J. de O.; ROCHA, M.; YAMADA, T. Cultura do feijoeiro fatores que afetam a produtividade. Piracicaba: Potafos, 1988. 596 p. 
